
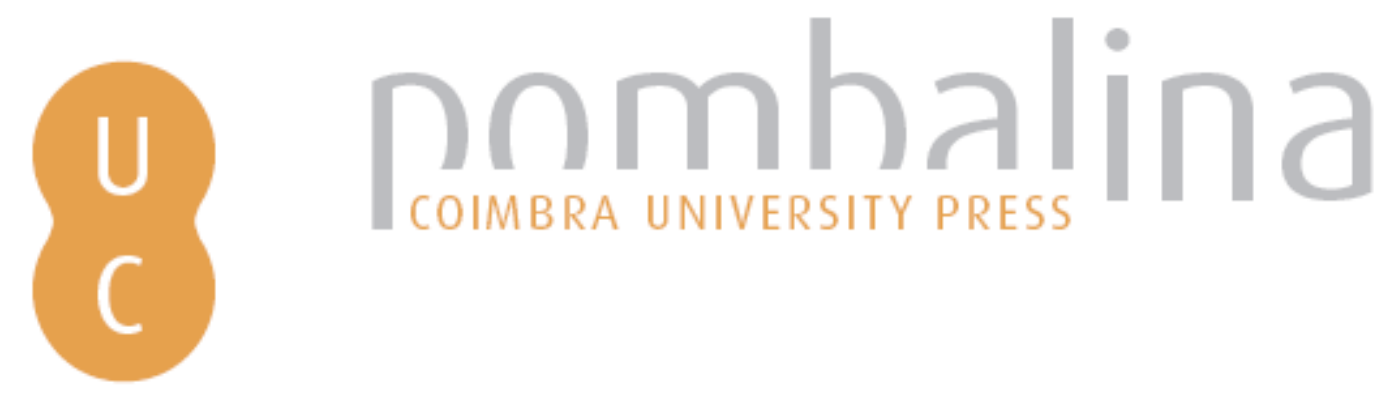

Fall from a height with head trauma: due to or complicated by cardiac dysfunction?: one case study
Autor(es):
Coelho, A. S.; Marques, C.; Sanches, R.; Cortesão, L.; Vieira, D. N.
Publicado por: Imprensa da Universidade de Coimbra
URL
persistente:
URI:http://hdl.handle.net/10316.2/31720
DOI:
DOI:http://dx.doi.org/10.14195/978-989-26-0173-1_80
Accessed : $\quad$ 26-Apr-2023 15:30:17

A navegação consulta e descarregamento dos títulos inseridos nas Bibliotecas Digitais UC Digitalis, UC Pombalina e UC Impactum, pressupõem a aceitação plena e sem reservas dos Termos e Condições de Uso destas Bibliotecas Digitais, disponíveis em https://digitalis.uc.pt/pt-pt/termos.

Conforme exposto nos referidos Termos e Condições de Uso, o descarregamento de títulos de acesso restrito requer uma licença válida de autorização devendo o utilizador aceder ao(s) documento(s) a partir de um endereço de IP da instituição detentora da supramencionada licença.

Ao utilizador é apenas permitido o descarregamento para uso pessoal, pelo que o emprego do(s) título(s) descarregado(s) para outro fim, designadamente comercial, carece de autorização do respetivo autor ou editor da obra.

Na medida em que todas as obras da UC Digitalis se encontram protegidas pelo Código do Direito de Autor e Direitos Conexos e demais legislação aplicável, toda a cópia, parcial ou total, deste documento, nos casos em que é legalmente admitida, deverá conter ou fazer-se acompanhar por este aviso.

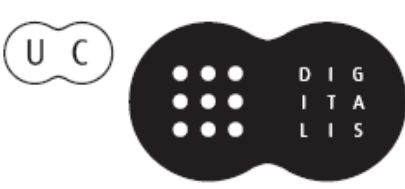




\section{Duarte Nuno Vieira Anthony Busuttil \\ Denis Cusack • Philip Beth}
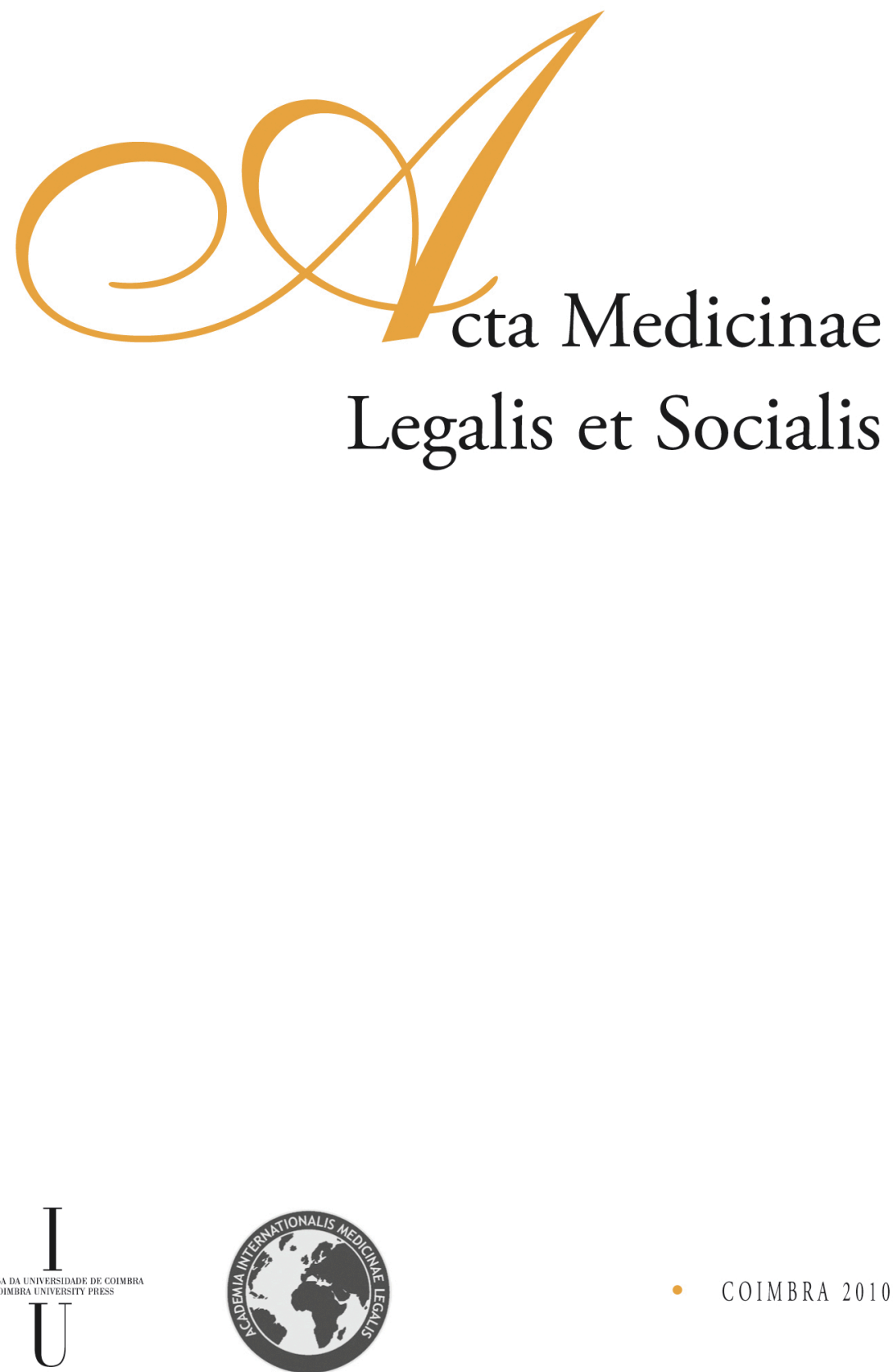
A. S. Coelho ${ }^{1}$, C. Marques $^{1}$, R. Sanches ${ }^{1}$, L. Cortesão ${ }^{2}$, D. N. Vieira ${ }^{1,3}$

${ }^{1}$ Centre Branch of the National Institute of Legal Medicine, Coimbra, Portugal

${ }^{2}$ Leiria Legal Medicine Office, National Institute of Legal Medicine, Leiria, Portugal

${ }^{3}$ Faculty of Medicine, University of Coimbra, Portugal

\title{
FALL FROM A HEIGHT WITH HEAD TRAUMA: DUE TO OR COMPLICATED BY CARDIAC DYSFUNCTION? ONE CASE STUDY
}

\begin{abstract}
This paper refers to a case of clinical forensic evaluation, in terms of labour law, the patient evoking the existence of cardiac sequelae supervening head trauma, due to a fall from a height. Beside a brief reflexion on this pathological entity, the authors also pretend to illustrate the importance of an accurate analysis of all available data, from patient interview to clinical documentation, in order to establish the causal nexus.
\end{abstract}

\section{Introduction and objectives}

A wide variety of cardiac changes following acute head injury have been described, mainly concerning heart rate and rhythm, traducing it selves by EKG abnormalities, and are believed to be due to autonomic nervous system dysfunction (table 1), prevailing the sympathetic system activation, in the context of the acute stress response to trauma, with rising of circulating cathecolamine levels. Therefore, taquiarrythmias are more frequent than bradiarrythmias, the most commonly described being the supraventricular tachycardia. These changes have been reported even after minor head injuries and are usually reversible, showing a parallel course within the patient' neurological status. In the present case, the main question to answer was whether the accident was due to atrio-ventricular blockade (as evidenced by the EKG performed at the moment of medical emergency assistance), followed by syncope, or if the accident itself, resulting in head trauma, caused the atrio-ventricular blockade and could therefore be responsible for the present clinical condition of the patient.

\section{Case Study}

A 49 years-old man fell from a machine, 3 metres high, while working, which was followed by immediate loss of consciousness. He was promptly assisted by emergency medical professionals and immediately admitted to an intensive care unit. A temporary pacemaker was implanted and the patient went under a tracheostomy and mechanical ventilation, among other therapeutic measures, including suture of a blunt trauma 
wound of the frontal region. Physical and imaging evaluation revealed the absence of any neurological disorder, namely of traumatic origin, reliable to justify the patient clinical status. In fact, fracture of the left side of the frontal bone and an isolated, small dimensioned, focal brain lesion (in the basal aspect of the frontal lobe), were the only traumatic lesions evidenced by CTScanning.

Concerning the circumstances of the accident, no witnesses were around and the patient mentions immediate lost of consciousness and no memory of feeling ill previously to the fall. However a careful analysis of the clinical reports disclosed that the patient referred, in a previous consultation, that he fell over after stopping the machine because he was actually not feeling good and was bleeding from the nose. Furthermore, it is referred, in the nursery clinical notes, during the patient's hospitalization, that about three days before the accident he began feeling ill, with the onset of dyspneia and orthopnea, with no clinical signs of an respiratory infectious disorder.

Finally, the patient revealed his clinical history, dominated by prior cardiac disorder, under pharmacological therapy.

In fact, full documentation on cardiac previous history, revealed dilated cardiomiopathy of unknown/non-defined aetiology and cardiac heart failure with ventricular arrhythmia and dysfunction. There was indeed described the necessity of temporary pacemaker implantation, during an surgical procedure, in order to prevent bradycardia.

Presently, the patient has a permanent pacemaker and is medicated with antihypertensive and anti-arrhythmic drugs. A brief neurological physical examination revealed no abnormalities, and the actual symptoms the patient complains about include episodes of headache, dizziness and irritability as well as fatigue.

\section{Discussion and Conclusion}

The establishment of causal nexus between a traumatic event and a given clinical condition, claimed to represent its sequelae, depends on several assumptions, which include, among others, the absence of other putative causes for that clinical condition as well as the absence of it's pre-existence.

In the present case, the analyses of the data concerning the history of this patient's case, by one hand, and, on the other hand, the acquaintance of the scientific literature, permits the establishment of elements voting in favour of and against the existence of causal nexus between the traumatic event suffered by the patient while working, resulting in head trauma, and the atrio-ventricular blockade, as well as his present cardiac dysfunction, as he reclaims.

So, voting in favour of this hypothesis is the occurrence of an atrio-ventricular blockade, immediately after a documented head trauma, being that condition one of the most frequently cardiac arrythmias reported with Central Nervous System pathology. However, stronger factors, such as the patient previous clinical condition and the persistence of cardiac dysfunction after the recovering and until the present time, vote against the patient's postulated causative theory. 
In fact, and despite the above mentioned scientifically proved relation between cardiac rhythm disturbance and head trauma, including minor traumatic events, one could never neglect the patient's previous clinical history of complex and long-term cardiac disorders, to be the main suspect of being responsible for the occurred event, and so the more plausible scenario being the occurrence of a syncope followed by a fall, which in its turn caused the traumatic minor head lesions reported. Furthermore, there is a strong possibility that the epistaxis episode mentioned in the clinical reports, as preceding the traumatic event, was related with a sudden rise of arterial blood pressure, i.e, an hypertensive crises, which is in turn, a frequent condition associated with cardiomiopathy and heart failure. Another feature, in this case, pointing towards this theory versus the hypothesis of cardiac arrhythmias caused by head trauma, was the patient clinical outcome, with the maintenance of the disrythmia, in contrast with the reversible character of heart dysfunction due to head trauma, which tends to disappear once the acute phase of brain injury is solved. It is indeed established, in the literature review, the reversibility of cardiac disrythmic status as a main feature, when of traumatic origin.

Beside alerting to the probability of cardiac dysfunction succeeding to head injury, which is in fact an unusual documented condition, and therefore displacing a delicate matter in terms of causal nexus establishment, namely when no previous cardiac condition is reported, this paper emphasizes the importance of an accurate medical interview, and mostly of a complete clinical report of the event as well as concerning patient's clinical history, when determining the causal nexus between a traumatic event and the present clinical condition of the patient.

\section{References}

CHESNUT R. (1993) Head Injury. 3rd ed. 459-501.

HERSCH C. (1961) Electrocardiographic Changes in Head Injuries. Circulation 23: 853-860.

MCLEOD A. et al (1982) J. Cardiac sequelae of acute head injury. Br Heart J; 47:221-6.

\begin{tabular}{|l|l|}
\hline ECG changes & Cardiac arrythmias \\
\hline High-amplitude P waves & Sinus bradicardya \\
\hline Increased CRS voltage & Supraventricular tachycardia \\
\hline Q waves & Atrial fibrillation \\
\hline Prolonged QT interval & Atrioventricular blockade \\
\hline Shortened QT interval & Ectopiventricular contractions \\
\hline Depressed ST & Multifocal ventricular tachycardia \\
\hline Elevated ST segments & Ventricular flutter \\
\hline T wave flattening & Ventricular fibrillation \\
\hline T wave inversion & Left axis deviation \\
\cline { 1 - 1 } Tall, peaked T waves & \\
\cline { 1 - 1 } Notched T waves & \\
\cline { 1 - 1 } U waves & \\
\cline { 1 - 2 } Pulsus alternans & \\
\cline { 1 - 2 } U waves alternans &
\end{tabular}

Table 1 - EKG changes and Cardiac Arrythmias with CNS Pathology 